Research Article

\title{
A study of pleural effusion with reference to different diagnostic modalaties
}

\author{
Savita Jindal $^{1}{ }^{*}$, Pankaj Garg $^{2}$, Amit R. Dedun ${ }^{1}$, Hemant Nayi ${ }^{1}$, Divyashree $\mathbf{J}^{1}$, Gaurav Sahu ${ }^{1}$
}

${ }^{1}$ Department of Pulmonary Medicine, B.J. Medical College, Ahmedabad, Gujarat, India

${ }^{2}$ Department of Medicine, GMERS Medical College, Gandhinagar, Gujarat, India

Received: 25 July 2015

Revised: 27 July 2015

Accepted: 20 August 2015

\section{*Correspondence:}

Dr. Savita Jindal,

E-mail: drsavy05@gmail.com

Copyright: (C) the author(s), publisher and licensee Medip Academy. This is an open-access article distributed under the terms of the Creative Commons Attribution Non-Commercial License, which permits unrestricted non-commercial use, distribution, and reproduction in any medium, provided the original work is properly cited.

\begin{abstract}
Background: Aim of current study was to determine the different etiologies of pleural effusion and efficacy of diagnostic methods.

Methods: 100 patients of pleural effusion of both sexes were taken randomly coming to our institution either indoor or OPD. Inclusion criteria: 100 patients of pleural effusion of any age and of either sex in whom thoracentesis can yield minimum amount of pleural fluid for diagnostic purposes. Exclusion criteria: Patients of pleural effusion in whom fluid could not be aspirated were excluded from the study.

Results: In this study $70 \%$ of the patients were male and $30 \%$ were female. Most of the patients were between 21-30 years of age. $92 \%$ of the pleural effusion was exudative and $8 \%$ was transudative. Tuberculosis is the most common (44\%) cause of pleural effusion followed by malignancy $(23 \%), 5 \%$ of the patients remains undiagnosed. Sensitivity, specificity, NPV, PPV of Light's criteria is $100 \%$ to differentiate between transudates and exudates. Among parameters of Light's criteria pleural LDH has highest specificity (100) and sensitivity (100) and NPV (80\%). Sensitivity, specificity, NPV, PPV of ADA to differentiate between tuberculous and non tuberculous pleural effusion is $100 \%, 95 \%, 100 \%, 96.77 \%$ respectively. Pleural biopsy was positive in $80 \%$ of the tuberculous patients while in malignancy it was positive only in $20 \%$ of the patients.

Conclusions: Tuberculosis remains to be main cause of pleural effusion in India. Light's criteria is most specific \& sensitive to diagnose between exudative \& transudative pleural fluid. ADA is highly sensitive $\&$ specific to differentiate between tuberculous \& nontuberculous pleural effusion. In centres where thorascopy is not available for undiagnostic cases of pleural effusion, pleural biopsy can be helpful in fair no. of cases for diagnosis.
\end{abstract}

Keywords: Pleural effusion (PE), Adenosine deaminase (ADA), Malignancy

\section{INTRODUCTION}

Someone has rightly said that pleural effusion is not a disease, but it is the sign of many diseases. It constitutes a major problem in all areas of clinical medicine. That is why examination of pleural fluid and pleura gives clue to the diagnosis of so many diseases. A patient with pleural effusion may present to chest physician or to general surgeon. ${ }^{1}$ Collection of fluid has many etiological factors.
In India tuberculosis is the most common cause followed by malignancy. ${ }^{2-4}$ Pleural effusion often poses a diagnostic dilemma to the physician as differential diagnosis is wide. The major problem in clinical diagnosis of pleural effusion is not distinguishing transudates from exudates ${ }^{2,5}$ but is determining the cause of effusion, when it is an exudate. For this reason many laboratory correlation have been made with various diseases known to cause exudative effusion. Sometimes 
diagnosis may be made easily but sometimes pleural effusion remain as undiagnosed. ${ }^{6-8}$ Light et al. has established a criteria demonstrating high degree of diagnostic accuracy for differentiating transudates and exudates. $^{9}$

Adenosine deaminase (ADA) is an enzyme, as a marker of cellular immunity, its activity is found to be elevated in diseases, in which there is cell mediated immune response. $^{10-12}$

\section{METHODS}

100 patients of pleural effusion of both sexes were taken randomly coming to our institution either indoor or OPD.

\section{Inclusion criteria}

100 patients of pleural effusion of any age and of either sex in whom thoracentesis can yield minimum amount of pleural fluid for diagnostic purposes.

\section{Exclusion criteria}

Patients of pleural effusion in whom fluid could not be aspirated were excluded from the study.

\section{RESULTS}

Table 1 shows $($ Total) mean age $=37.80 \pm 15.47$ mean age in $\mathrm{TB}=32.18 \pm 15.47$ and in Malignancy $=53.63 \pm$ 18.93.This table shows that most of the patients $(41 \%)$ were between the age group 21-30 years. $70 \%$ of the patients were male while $30 \%$ of the patients were female, shows male preponderance.

Table 1: Age and sex distribution.

\begin{tabular}{|llll|}
\hline $\begin{array}{l}\text { Age group } \\
\text { (years) }\end{array}$ & Males & Females & Total \\
\hline $11-20$ & 03 & 01 & 04 \\
\hline $21-30$ & 28 & 13 & 41 \\
\hline $31-40$ & 09 & 05 & 14 \\
\hline $41-50$ & 10 & 05 & 15 \\
\hline $51-60$ & 16 & 05 & 21 \\
\hline More than 60 & 04 & 01 & 05 \\
\hline Total & 70 & 30 & 100 \\
\hline
\end{tabular}

Table 2 shows that maximum number of cases of pleural effusion were tuberculosis (44\%), followed by malignancy $(23 \%)$ and parapneumonic $(13 \%) .5 \%$ of the cases of pleural effusion remain undiagnosed.

Table 3: Majority of patient had right sided effusion. $80 \%$ of patients in CCF had bilateral pleural effusion. $52.17 \%$ of the malignant pleural effusion has right sided pleural effusion. Right sided effusion is more in tuberculous and in malignancy. Majority $(80 \%)$ of the patients of $\mathrm{CCF}$ had bilateral pleural effusion.
Table 2: Etiological diagnosis of pleural effusion.

\begin{tabular}{|c|c|c|c|c|}
\hline \multirow{2}{*}{ Diagnosis } & \multicolumn{2}{|c|}{ No. of cases } & \multirow{2}{*}{ Total } & \multirow{2}{*}{$\begin{array}{l}\text { Percentage } \\
(\%)\end{array}$} \\
\hline & Male & Female & & \\
\hline TB & 28 & 16 & 44 & 44 \\
\hline Malignancy & 18 & 5 & 23 & 23 \\
\hline Parapneumonic & 9 & 4 & 13 & 13 \\
\hline $\mathrm{CCF}$ & 5 & 0 & 5 & 5 \\
\hline Cirrhosis of liver & 1 & 0 & 1 & 1 \\
\hline $\begin{array}{l}\text { Ruptured liver } \\
\text { abscess }\end{array}$ & 1 & 0 & 1 & 1 \\
\hline Hypoproteinemia & 0 & 1 & 1 & 1 \\
\hline Chylothorax & 1 & 0 & 1 & 1 \\
\hline $\begin{array}{l}\text { Constrictive } \\
\text { pericarditis }\end{array}$ & 1 & 0 & 1 & 1 \\
\hline $\begin{array}{l}\text { Chronic } \\
\text { pancreatitis }\end{array}$ & 2 & 0 & 2 & 2 \\
\hline $\begin{array}{l}\text { Collagen } \\
\text { vascular diseases }\end{array}$ & 0 & 2 & 2 & 2 \\
\hline $\begin{array}{l}\text { Hydatid cyst } \\
\text { rupture }\end{array}$ & 1 & 0 & 1 & 1 \\
\hline Undiagnosed & 3 & 2 & 5 & 5 \\
\hline Total & 70 & 30 & 100 & 100 \\
\hline
\end{tabular}

Table 3: Side of effusion.

\begin{tabular}{|llll|}
\hline Diagnosis & Right $(\%)$ & Left $(\%)$ & $\begin{array}{l}\text { Bilateral } \\
(\%)\end{array}$ \\
\hline TB (44) & $24(54.54)$ & $18(40.90)$ & $2(4.54)$ \\
\hline Malignancy (23) & $12(52.17)$ & $9(39.13)$ & $2(8.69)$ \\
\hline Parapneumonia (13) & $10(76.92)$ & $3(23.67)$ & 0 \\
\hline CCF (5) & $1(20)$ & 0 & $4(80)$ \\
\hline Cirrhosis of liver (1) & $1(100)$ & 0 & 0 \\
\hline $\begin{array}{l}\text { Ruptured liver } \\
\text { abscess (1) }\end{array}$ & $1(100)$ & 0 & 0 \\
\hline Hypoprotenaemia (1) & $1(100)$ & 0 & 0 \\
\hline Chylothorax (1) & 0 & 0 & $1(100)$ \\
\hline $\begin{array}{l}\text { Constrictive } \\
\text { pericarditis (1) }\end{array}$ & 0 & 0 & $1(100)$ \\
\hline $\begin{array}{l}\text { Chronic pancreatitis } \\
\text { (2) }\end{array}$ & 0 & 0 & $2(100)$ \\
\hline $\begin{array}{l}\text { Collagen vascular } \\
\text { disease (2) }\end{array}$ & $1(50)$ & $1(50)$ & 0 \\
\hline $\begin{array}{l}\text { Hydatid cyst rupture } \\
(1)\end{array}$ & $1(100)$ & 0 & 0 \\
\hline Undiagnosed (5) & $2(40)$ & $3(60)$ & 0 \\
\hline Total (100) & 56 & 34 & 10 \\
\hline Percentage & 56 & 34 & 10 \\
\hline
\end{tabular}

Table 4 shows that $92 \%$ of the patients of present study were having exudative pleural effusion and $8 \%$ of the patients had transudative pleural effusion.

Table 5 shows that tuberculous, malignant and parapneumonic pleural effusion had pleural fluid glucose level less than $60 \mathrm{mg} / \mathrm{dL}$. All the tuberculous pleural effusion has ADA level more than $40 \mathrm{mg} / \mathrm{dL} .93 .3 \%$ of 
the malignant pleural effusion and all other pleural effusion have ADA less than $40 \mathrm{mg} / \mathrm{dL}$. Only $6.67 \%$ of the malignant pleural effusion has ADA level more than
$40 \mathrm{mg} / \mathrm{dL} .85 \%$ of the all patients have cholesterol level $>60 \mathrm{mg} / \mathrm{dL}$.

Table 4: Biochemical analysis of pleural fluid (Light's criteria).

\begin{tabular}{|c|c|c|c|c|c|c|}
\hline \multirow{2}{*}{ Diagnosis } & \multicolumn{2}{|c|}{$\begin{array}{l}\text { Pleural fluid Prt./S. prt. } \\
(100)(\%)\end{array}$} & \multicolumn{2}{|c|}{$\begin{array}{l}\text { Pleural fluid LDH } \\
(60 \mathrm{X} \%)\end{array}$} & \multicolumn{2}{|c|}{$\begin{array}{l}\text { Pleural fluid /S. LDH } \\
(60 \times \%)\end{array}$} \\
\hline & $>0.5$ & $<0.5$ & $<200$ & $>200$ & $<0.6$ & $>0.6$ \\
\hline TB (44) & 44 & - & $1(3.34)$ & $29(96.67)$ & 2 & 28 \\
\hline Malignancy (23) & $22(95.65)$ & $1(4.34)$ & 0 & $15(100)$ & 0 & 15 \\
\hline Parapneumonia (13) & $12(92.30)$ & $1(7.69)$ & $1(20)$ & $4(80)$ & 1 & 4 \\
\hline $\mathrm{CCF}(5)$ & 0 & $5(100)$ & $5(100)$ & - & 5 & 0 \\
\hline Cirrhosis of liver (1) & 0 & $1(100)$ & $1(100)$ & - & 1 & 0 \\
\hline Ruptured liver abscess (1) & $1(100)$ & - & - & - & - & - \\
\hline Chylothorax (1) & $1(100)$ & - & - & $1(100)$ & - & 1 \\
\hline Hypoproteinemia (1) & 0 & $1(100)$ & $1(100)$ & - & 1 & - \\
\hline Constrictive pericarditis (1) & $1(100)$ & - & $1(100)$ & - & 1 & - \\
\hline Chronic pancreatitis (2) & $2(100)$ & - & - & - & - & - \\
\hline Collagen vascular disease (2) & $2(100)$ & - & - & - & - & - \\
\hline Hydatid cyst ruptures (1) & $1(100)$ & - & 0 & $1(100)$ & - & 1 \\
\hline Undiagnosed (5) & $5(100)$ & - & - & - & - & - \\
\hline Total (100) & 91 & 9 & 10 & 50 & 11 & 49 \\
\hline Percentage & 91 & 9 & 16.66 & 83.34 & 18.33 & 81.67 \\
\hline
\end{tabular}

Table 5: Other laboratory parameters.

\begin{tabular}{|c|c|c|c|c|c|c|}
\hline \multirow{2}{*}{ Diagnosis } & \multicolumn{2}{|c|}{ (100) Pleural fluid } & \multicolumn{2}{|c|}{ PI. Fluid (ADA)(\%) } & \multicolumn{2}{|c|}{ (60) Pleural fluid } \\
\hline & $<60 \mathrm{mg} / \mathrm{dL}$ & $>60 \mathrm{mg} / \mathrm{dL}$ & $<40$ & $>40$ & $<60$ & $>60$ \\
\hline TB (44) & $43(9772)$ & $1(2.27)$ & 0 & $30(100)$ & 0 & $30(100)$ \\
\hline Malignancy (23) & $22(95.65)$ & $1(4.34)$ & $14(13.3)$ & $1(6.67)$ & $1(13.3)$ & $14(93.3)$ \\
\hline Parapneumonia (13) & $13(100)$ & 0 & $2(100)$ & - & 0 & $5(100)$ \\
\hline $\mathrm{CCF}(5)$ & 0 & $5(100)$ & $1(100)$ & - & $5(100)$ & - \\
\hline Cirrhosis of liver (1) & 0 & $1(100)$ & - & - & $1(100)$ & - \\
\hline Ruptured liver abscess (1) & $1(100)$ & - & - & - & - & - \\
\hline Chylothorax (1) & $1(100)$ & 0 & $1(100)$ & - & - & $1(100)$ \\
\hline Hypoproteinemia (1) & 0 & $1(100)$ & - & - & $1(100)$ & - \\
\hline Constrictive pericarditis (1) & 0 & $1(100)$ & $1(100)$ & - & $1(100)$ & - \\
\hline Chronic pancreatitis (2) & 0 & $2(100)$ & - & - & - & - \\
\hline Collagen vascular disease (2) & $1(50)$ & $1(50)$ & - & - & - & - \\
\hline Hydatid cyst ruptures (1) & 0 & $1(100)$ & - & - & 0 & $1(100)$ \\
\hline Undiagnosed (5) & 0 & $5(100)$ & - & - & - & - \\
\hline Total (100) & 86 & 14 & 19 & 31 & 9 & 51 \\
\hline Percentage & 86 & 14 & 38 & 62 & 15 & 85 \\
\hline
\end{tabular}

Table 6 shows that in transudates mean SD of ratio of pleural fluid to serum protein is less than 0.5 while in exudates it is $>0.5$. Mean value of other parameters of Lights criteria also fulfils the Lights criteria in transudates and exudates.

Table 7 shows that Light's criteria is most specific and sensitive indicator to distinguish between transudates and exudates. In Light's criteria pleural fluid/S. prt is most sensitive $(97.8 \%)$ while pleural fluid LDH as well as its ratio to $\mathrm{S}$. $\mathrm{LDH}$ is most specific $(100 \%)$.

Table 8 shows that ADA is the sensitive parameter to differentiate between tuberculous and non tuberculous pleural effusion.

Table 9 shows that in majority of the tuberculous pleural effusion (80\%) pleural biopsy confirms the diagnosis 
while in malignancy only few patients (20\%) diagnosis is confirmed by biopsy. The reason may be that in tuberculous whole pleural membrane is inflamed while in malignancy patchy inflammation is there.

Table 6: Mean value and standard deviation of different biological parameters in transudate, exudates, tuberculous and malignant pleural effusion.

\begin{tabular}{|lllll|}
\hline Parameters & $\begin{array}{l}\text { Transudates } \\
(\text { Mean } \pm \text { SD) }\end{array}$ & $\begin{array}{l}\text { Exudates } \\
\text { (Mean } \pm \text { SD) }\end{array}$ & $\begin{array}{l}\text { Tuberculous } \\
\text { (Mean } \pm \text { SD) }\end{array}$ & $\begin{array}{l}\text { Malignant } \\
\text { (Mean } \pm \text { SD) }\end{array}$ \\
\hline Pleural fluid Prt./S. prt. & $0.32 \pm 0.09(8)$ & $0.71 \pm 0.14(92)$ & $0.715 \pm 0.127(44)$ & $0.69 \pm 0.127(23)$ \\
\hline Pleural fluid LDH & $160.0 \pm 23.523(8)$ & $376.34 \pm 111.25(52)$ & $363.03 \pm 103.17(30)$ & $421.6 \pm 117.17(15)$ \\
\hline Pleural fluid LDH i.e. S. LDH & $0.48 \pm 0.077(8)$ & $0.87 \pm 0.391(52)$ & $0.848 \pm 0.34(30)$ & $0.99 \pm 0.516(15)$ \\
\hline Pleural fluid Glu. & $94 \pm 19.8(8)$ & $36.46 \pm 24.89(92)$ & $40.70 \pm 25.80(44)$ & $36.56 \pm 21.62(23)$ \\
\hline Pleural fluid ADA & $23.5 \pm 4.04(2)$ & $63.06 \pm 31.51(48)$ & $84.16 \pm 18.38(30)$ & $30.2 \pm 7.26(15)$ \\
\hline Pleural fluid cho. & $47.36 \pm 10.96(8)$ & $112.54 \pm 45.16(52)$ & $118.0 \pm 19.45(30)$ & $88.26 \pm 19.27(15)$ \\
\hline
\end{tabular}

Table 7: Sensitivity, specificity, positive predictive value (PPV) and negative predictive value (NPV) of various laboratory parameters for transudate.

\begin{tabular}{|lllll|}
\hline $\begin{array}{l}\text { Parameters } \\
\text { cut off value) }\end{array}$ & $\begin{array}{l}\text { Sensitivity } \\
(\%)\end{array}$ & $\begin{array}{l}\text { Specificity } \\
(\%)\end{array}$ & $\begin{array}{l}\text { PPV } \\
(\%)\end{array}$ & $\begin{array}{l}\text { NPV } \\
(\%)\end{array}$ \\
\hline $\begin{array}{l}\text { Pleural fluid/ } \\
\text { S. prt. (0.5) }\end{array}$ & 97.8 & 87.5 & 98.9 & 77.77 \\
\hline $\begin{array}{l}\text { Pleural fluid } \\
\text { LDH (200) }\end{array}$ & 96.15 & 100 & 100 & 80 \\
\hline $\begin{array}{l}\text { Pleural fluid/ } \\
\text { S. LDH (0.6) }\end{array}$ & 94.23 & 100 & 100 & 72.72 \\
\hline Light's criteria & 100 & 100 & 100 & 100 \\
\hline
\end{tabular}

Table 8: Sensitivity, specificity, NPV, PPV of pleural fluid ADA.

\begin{tabular}{|lllll|}
\hline Diagnosis & $\begin{array}{l}\text { Sensitivity } \\
(\%)\end{array}$ & $\begin{array}{l}\text { Specificity } \\
(\%)\end{array}$ & $\begin{array}{l}\text { NPV } \\
(\%)\end{array}$ & $\begin{array}{l}\text { PPV } \\
(\%)\end{array}$ \\
\hline $\begin{array}{l}\text { Tuberculous } \\
\text { (40) pleural } \\
\text { effusion }\end{array}$ & 100 & 95 & 100 & 96.77 \\
\hline $\begin{array}{l}\text { Non-tuberculous } \\
\text { pleural effusion } \\
(30)\end{array}$ & 95 & 100 & 96.77 & 100 \\
\hline
\end{tabular}

Table 9: Pleural biopsy.

\begin{tabular}{|lll|}
\hline Diagnosis & $\begin{array}{l}\text { Positive for } \\
\text { diagnosis (\%) }\end{array}$ & $\begin{array}{l}\text { Negative for } \\
\text { diagnosis (\%) }\end{array}$ \\
\hline Tuberculous (20) & $16(80)$ & $4(20)$ \\
\hline Malignancy (5) & $1(20)$ & $4(80)$ \\
\hline Total (25) & 17 & 10 \\
\hline Percentage & 68 & 32 \\
\hline
\end{tabular}

Pleural fluid for ZN stain was done in all pleural effusion, (it was positive in $2(4.54 \%)$ patients out of 44 patients of tuberculous pleural effusion) the reason for this is that pleural effusion is the result of inflammation of pleura due to DTH (Delayed Type of Hypersensitivity). Pleural fluid AFB (Acid Fast Bacilli) present only if the' subpleural focus ruptures into pleural cavity.

In all suspected cases of parapneumonic pleural effusion gram stain for pleural fluid was done. Out of 13 parapneumonic patients $7(53.64 \%)$ were positive for gram stain.

In all malignant pleural effusion cytology of the pleural fluid was carried out. (It was positive in $15(65.21 \%)$ of the patients out of 23 patients.

\section{DISCUSSION}

In this study tuberculosis pleural effusion is $44 \%$ while it varies in different studies. Malignant pleural effusion is $23 \%$ which is comparable to Thiruvengadam (1962), ${ }^{13}$ Valdes (1991), ${ }^{14}$ Valdes (1996). ${ }^{10}$ Parapneumonic pleural effusion is $13 \%$ which is comparable to Hirsch (1979), ${ }^{8}$ Valdez (1991), ${ }^{14}$ Valdez (1996) ${ }^{10}$ J. E. Heffner (2002), ${ }^{15}$ J. E. Heffner (2003). ${ }^{16} \mathrm{CCF}$ effusion is $5 \%$ which is comparable to Thiruvengadam (1962). ${ }^{13}$ In present study common age group among all patients is $21-30$ years which is comparable to Irani et al. study. ${ }^{17}$ In present study mean age is $37.8 \pm 15.47$ which is comparable to $\mathrm{N}$. K. Menon. ${ }^{18}$

In present study $92 \%$ of the patients had exudative pleural effusion which is comparable to S. Ramero ${ }^{19}$ and Valdes study ${ }^{20}$ and $8 \%$ of the patients had transudative pleural effusion, in other studies percentage of transudate pleural effusion is very high. This may be due to high incidence of tuberculosis in India.

Sensitivity, specificity, PPV (Positive Predictive Value), NPV (Negative Predictive Value) of PF (Pleural Fluid)/S. Prt. (Serum Protein) in present study is $97.8 \%, 87.5 \%$, $98.9 \%, 77.77 \%$ respectively which comparable to Light's study. ${ }^{9}$ 
PI./Fluid LDH (Lactate Dehydrogenase) sensitivity, specificity, PPV, NPV in present study is 96.15, 100, $100 \%, 80 \%$ respectively which comparable to Light's ${ }^{9}$ and John E. Heffner's ${ }^{21}$ study.

Mean SD (Standard Deviation) of ADA in tuberculous pleural effusion was 84.16 in present study, which is comparable to Piras MA et al., ${ }^{12}$ Gilhotra ${ }^{22}$ study, while in non-tuberculous it was 30.2 which is comparable to Gilhotra $^{22}$ study

Sensitivity, NPV of ADA in present study was $100 \%$ which is same as that of B.R. Maldhure. ${ }^{4}$ Which shows ADA is a sensitive parameter to differentiate between tuberculous and non tuberculous pleural effusion.

In present study pleural biopsy is present in $68 \%$ of the patients which is comparable to Lloyd M.S. study. ${ }^{23}$ In present study pleural fluid for AFB preset in $4.54 \%$ which is same as that of Pranay Sinha study. ${ }^{24}$ In this study pleural fluid cytology for malignant cell in malignancy was present in $65.21 \%$ of the malignant pleural effusion patients which was comparable to Salyer study. $^{25}$

\section{Summary}

100 cases of pleural effusion were studied by clinical, radiological and various laboratory methods. In this study $70 \%$ of the patients were male and $30 \%$ were female. Most of the patients were between 21-30 years of age. $92 \%$ of the pleural effusion was exudative and $8 \%$ was transudative. Tuberculosis is the most common (44\%) cause of pleural effusion followed by malignancy (23\%), $5 \%$ of the patients remains undiagnosed.

Right sided effusion was present in $56 \%$ patients while left sided in $34 \%$ and $10 \%$ of the patients had bilateral pleural effusion. $46 \%$ of the patients had yellowish colour fluid followed by $23 \%$ of the patients with haemorrhagic pleural effusion, followed by $13 \%$ purulent. Yellowish colour fluid was present in $84.09 \%$ of the tuberculous patients while common cause of haemorrhagic pleural fluid was malignancy $(69.56 \%)$ only $1 \%$ of the patient with chylothorax was having milky white pleural effusion. $76.92 \%$ of the patients with parapneumonic pleural effusion had purulent pleural fluid. All the transudates pleural fluid had clear fluid.

Sensitivity, specificity, NPV, PPV of Light's criteria is $100 \%$ to differentiate between transudates and exudates. Among parameters of Light's criteria pleural LDH has highest specificity (100) and sensitivity (100) and NPV $(80 \%)$.

Sensitivity, specificity, NPV, PPV of ADA to differentiate between tuberculous and non tuberculous pleural effusion is $100 \%, 95 \%, 100 \%, 96.77 \%$ respectively. Pleural biopsy was positive in $80 \%$ of the tuberculous patients while in malignancy it was positive only in $20 \%$ of the patients. Pleural fluid for AFB was present in $4.54 \%$ of the tuberculous patients. $65.21 \%$ of the malignant pleural effusion, pleural fluid cytology for malignant cells was present.

\section{CONCLUSION}

In day to day practice we come across cases of pleural effusion, usually to diagnose pleural effusion not a difficult task but still some cases requires detailed examination but number of these cases are few. By doing specific tests like pleural biopsy, pleural fluid ADA we can significantly improve diagnostic yield as these tests are, easily approachable and non-invasive or minimally invasive and can significantly reduce hospitalization period. In centres where thoracoscopy is not available for undiagnostic cases of pleural effusion, pleural biopsy can be helpful in fair no. of cases for diagnosis.

Funding: No funding sources

Conflict of interest: None declared

Ethical approval: The study was approved by the institutional ethics committee

\section{REFERENCES}

1. Edmund Leuallen, Carr David. Pleural effusion: a study of 436 patients. $\mathrm{N}$ Engl $\mathrm{J}$ Med. 1955;252(3):156-60.

2. Light RW, Glickmen RM, Isselbreher K. Disorders of pleura, mediastinum and diaphragm. In: Light RW, Glickmen RM, Isselbreher K, eds. Harrison's Principle of Internal Medicine. 14th ed. New York: McGraw-Hill; 1998: 1473-1476.

3. Sharma SK, Suresh V, Mohan A, Kaur P. A prospective study of sensitivity and specificity of adenosine deaminase estimation in the diagnosis of tuberculosis pleural effusion. Indian $\mathrm{J}$ Chest Dis Allied Sci. 2001;43(3):155.

4. Maldhure BR, Bedarkar SP, Kulkami HR, Papinwar SP. Pleural biopsy and adenosine deaminase in pleural fluid for the diagnosis of tuberculous pleural effusion. Indian J Tuberc. 1994;41:161-5.

5. Burgess Lesley, Matiz Frans, Taljaard Frans. Comparative analysis of the biochemical parameter used to distinguish between pleural transudates and exudates. Chest. 1995;107(6):1604-9.

6. Hinrich, Hamm, Brohan Vwe. Cholesterol in pleural effusion: a diagnostic aid. Chest. 1987;92(2):296302.

7. Storey DD, Dines DE, Coles DT. Pleural effusion: a diagnostic dilemma. JAMA. 1976;236:2183-6.

8. Hirsch A, Ruffie P, Nebut M. Pleural effusion: laboratory tests in 300 cases. Thorax. 1979;34:10612.

9. Light Richard, Isabele Margregar. Pleural effusion: the diagnostic separation of transudates and exudates. Ann Intern Med. 1972;77:507-13.

10. L. Valdes, E. San Jose, D. Alvarez, J. M. Valle. ADA isoenzyme analysis in pleural effusions: 
diagnostic roll, and relevance to the origin of increased ADA in tuberculous. Pleursy Eur Respir J. 1996;9:747-51.

11. Subhakar K, Kotilengani K, Satyasri S. Adenosine deaminase activity in pleural effusion. Lung India. 1991;IX(2):57-60.

12. Piras MA, Gakis C, Budroni M, Andreoni G. Adenosine deaminase activity in pleural effusion: an aid to differential diagnosis. Br Med J. 1978;2:175.

13. Thiruvengadam D, Angali V, Madangopalan. Etiological diagnosis of punch biopsy of pleura. Dis Chest. 1962;42:529.

14. Valdes Luis, De Alvarez, Pose Antonio, Sudrez Javer. Cholesterol a useful parameter for distinguishing between pleural exudates \& transudates. Chest. 1991;99(5):1097-102.

15. Heffner JE, Sahn SA, Brown LK. Multilevel likelihood ratio for identifying exudative pleural effusion. Chest. 2002;121:1916-20.

16. Heffner JE, Highland K, Brown LK. A metaanalysis derivation of continuous likelihood ratio for diagnosing pleural fluid exudates. Am J Respir Crit Care Med. 2003;67:1591-9.

17. Irani R, Underwood Reba, Greenberg Donald. Malignant pleural effusion. Arch Int Med. 1987;147:1133-6.
18. Menon KN. Steroid therapy in tuberculous pleural effusion. Tubercle London. 1964;45:17-20.

19. Santiago Romero, L. Hernandez, D. Orts, C. Fernandez. Is it meaningful to use biochemical parameters to discriminate between transudative and exudative pleural effusions? Chest. 2002;122:15249.

20. Luis Valdes, De Alvarez, E San Jose. Tuberculous pleurisy: a study of 245 patients. Arch Intern Med. 1998;158:2017-21.

21. Heffher JE. Evaluating diagnostic tests in the pleural space. Clin Chest Med. 1998;9(2):277-93.

22. Gilhotra R, Seagal S, Jindal SK. Pleural biopsy \& ADA enzyme activity in effusions of different etiologies. Lung India. 1989;7(3):122-4.

23. Lloyd MS. Thoracoscopy \& biopsy in the diagnosis of pleurisy with effusion. Q Bull Sea View Hosp. 1953;14:128-33.

24. Sinha PK. Comparative sensitivity of mycobacterial culture, histopathology \& adenosine deaminase activity. JAPI. 1985;33(10):644-5.

25. Salyer WR. Efficacy of pleural needle biopsy \& pleural fluid pathology in the diagnosis of malignant neoplasm involving the pleura. Chest. 1975;67:536.

Cite this article as: Jindal S, Garg P, Dedun AR, Nayi H, Divyashree J, Sahu G. A study of pleural effusion with reference to different diagnostic modalaties. Int $\mathbf{J}$ Adv Med 2015;2:359-64. 